\title{
Does it pay to be green? Environmental performance and firm financing during COVID-19 outbreaks
}

Nirosha Hewa Wellalage

The University of Waikato https://orcid.org/0000-0002-3316-3813

Vijay Kumar ( $\nabla$ vijay.kumar@waikato.ac.nz )

The University of Waikato https://orcid.org/0000-0001-9100-5728

\section{Research Article}

Keywords: COVID-19, Micro, Small and Medium Enterprises (MSMEs), environmental performance, firm financing, environmental regulations

Posted Date: October 7th, 2020

DOI: https://doi.org/10.21203/rs.3.rs-83297/v1

License: () (7) This work is licensed under a Creative Commons Attribution 4.0 International License. Read Full License 


\section{Abstract}

This paper examines the effect of firm environmental performance on firm financing during the COVID-19 outbreak. Crises in multiple forms curtail Micro, Small and Medium Enterprises (MSMEs) stability and the livelihood of hundreds of millions of people who derive their living from these activities. The way in which MSMEs deal with crises and the extent to which environmental performance is beneficial when the market suffers a negative shock is relatively unexplored in the literature. We consider three aspects of financing - firm level liquidity, bank credit and bankruptcy probabilities - and argue that it pays for firms to show commitment to environmental responsibilities in a global pandemic. Through an examination of 3,356 MSMEs, we find that firms with better environmental performance reduce their probability of bankruptcies and their liquidities decreasing during the COVID-19 pandemic. Furthermore, analysis shows that the impact of a firm's environmental performance is more pronounced in sensitive industries (hospitality and retail). The results are robust based on a series of robustness checks, including propensity score matching and the Heckman two-stage sample selection model. Our study suggests that the trust between a firm and its stakeholders, if it is grounded on environmental performance, pays off when the overall level of trust in markets suffers a negative shock.

\section{JEL Classification: F64; G01; Q14}

\section{Introduction}

The coronavirus (COVID-19) outbreak was declared a global pandemic by the World Health Organisation (WHO) on March 11, 2020. Across the world, the number of confirmed cases exceeded 17 million, and the number of deaths exceeded 186 thousand people as of July $04,2020 .{ }^{[1]}$ To prevent the spread of the virus, several countries have taken strict measures which include regional and national lockdown. This has slowed down the economies and resulted in severe crises, such as a drastic decline in production and demand, cash flow problems, unemployment, and bankruptcies in most industries across the world (Papadopoulos et al. 2020).

Various countries have witnessed a significant decline in their gross domestic product (GDP); for example, the GDP of Eurozone has declined by $3.8 \%$ and the GDP of the United States has declined by $1.2 \%$ in the first quarter. ${ }^{[2]}$

The impact of the COVID-19 pandemic on Micro, Small and Medium Enterprises (MSMEs) ${ }^{[3]}$ is more severe than on larger companies (Bartik et al. 2020). In particular, MSMEs in the tourism and hospitality industries are severely affected. ${ }^{[4]}$ Recent studies provide evidence that $50 \%$ of some small firms have temporarily stopped operating and $60 \%$ of MSMEs are at risk of running out of cash reserves across the world (Bartik et al. 2020; Cowling et al. 2018). The International Trade Centre conducted a survey of MSMEs in 132 countries and found that the pandemic has strongly affected two-thirds of businesses, and one-fifth of businesses are likely to shut down in the next three months (International Trade Centre 2020). In the United States alone, the pandemic has led to the closure of $43 \%$ of MSMEs (Bartik et al. 2020).

Even in normal economic conditions, banks tend to consider MSMEs as high-risk borrowers because MSMEs are more prone to liquidity shortfalls and bankruptcies (Berger and Udell 1998). MSMEs are more inclined to asymmetric information and agency problems, as they often lack information and credit history (Beck and Demirguc-Kunt 2006). Weak property rights and inefficient insolvency practices further increase the risk of lending to MSMEs. Relationship banking prevents type II errors in MSME lending and in evaluating the creditworthiness of firms (Baas and Schrooten 2006). However, shocks such as the COVID-19 pandemic can severely disrupt this form of relationship lending (Lerner et al. 2020). The literature on the impact of COVID-19 on MSMEs is still sparse (Brown and Rocha 2020), although there is evidence to suggest that access to bank finance is more problematic for small firms during a global financial crisis (Demirguc-Kunt et al. 2020; N. Lee et al. 2015).

The environmental performance of firms has been a subject of interest for researchers and policymakers (Banerjee et al. 2019; Bragdon and Marlin 1972; Muhammad et al. 2015b; Porter and Van der Linde 1995; Williamson et al. 2006). Proactive environmental practices are exposed to a low degree of risk (Godfrey et al. 2009; Muhammad et al. 2015a), low cost of debt (Bauer and Hann 2010), easier access to the financial market (Jo and Na 2012), higher leverage (Sharfman and Fernando 2008) and better conditions on loans (Goss and Roberts 2011; Magnanelli and Izzo 2017). Nevertheless, some studies report that the financial risk incurred by socially and environmentally responsible firms is higher than other firms (Kiernan 2007; Seeger and Hipfel 2007). Overall, empirical studies relating to environmental performance and firm financing appear inconclusive (D. Lee and Faff 2009) and most of these investigate the relationship within normal economic conditions. How environmental performance impacts on firm financing when the market suffers a negative shock is relatively unexplored in the literature ${ }^{[5]}$. By examining SMEs in seven countries in the context of the COVID-19 pandemic, our study aims to bridge this knowledge gap and focuses on three different aspects of financing: liquidity; access to bank financing; and bankruptcy.

From a stakeholder perspective, theoretical identification of the effect of environmental performance on firm financing during the COVID-19 pandemic can be explained in terms of risk mitigation. Higher environmental performance by firms may decrease the likelihood of negative events at the firm level (Bouslah et al. 2018) and at the economic level (i.e., during financial crises and economic recessions) because such firms with established reputations as environmentally responsible are able to gain access to crucial resources (Branco and Rodrigues 2006; Zeidan et al. 2015). Moreover, firms with high environmental performance are regarded as more trustworthy by stakeholders who are likely to place a valuation premium on such firms even if overall institutional and market trust is low (Lins et al. 2019). Thus, relationship-based intangible assets (i.e. trust and customer loyalty) gained from corporate investment into environmental activities are particularly valuable in negative economic conditions (Godfrey 2005). It was observed that, during the COVID-19 pandemic, firms experienced liquidity decreases regardless of their size (Juergensen et al. 2020). Our study sets out to ascertain whether the environmental performance of firms affect the rates of decline in the liquidity of firms. If financial institutions do not recognise environmentally responsible practices as a 
means for firms to lower their level of idiosyncratic risk, then firms may suffer from a competitive disadvantage because investments into environmentally responsible practices lead to costly diversions of the firm's resources (Goss and Roberts 2011).

Our findings suggest that it pays for firms to be green. In particular, the probit marginal effects show that one unit increase in environmental performance index decreases the probability of liquidity shortfall by 0.0172 and bankruptcy by 0.0077 during the pandemic. Furthermore, this impact of environmental performance on firm financing is more pronounced in firms from the hospitality and retail industries. The results are robust based on a series of robustness checks, including propensity score matching and the Heckman two-stage sample selection model. Our study proposes that the trust between a firm and its stakeholders, if it is grounded on environmental performance, holds firm when the overall level of trust in markets suffers a negative shock.

This study makes significant contributions to the literature in several respects. First, to the best of our knowledge, this is the first study to empirically investigate the impact of environmental performance on firm financing (liquidity, access to bank financing, and bankruptcy) during the COVID-19 pandemic. Empirical research on the effects of crisis events for MSMEs is scant, despite the fact that MSMEs tend to be the firms most deprived in a crisis event (Doshi et al., 2018). The limited research that exists on MSME financing in crisis periods (Brown and Rocha 2020; Cowling et al. 2018) has not touched on the environmental performance of firms in terms of MSME resilience and as a crisis management technique, which is what our study does.

Our paper is one of the few to test how environmental performance activities impact on MSME financing. The majority of research investigating this topic have examined firms in a developed region (Goss and Roberts 2011; Muhammad et al. 2015a, 2015b) ${ }^{[6]}$, whereas our study sample dominated by firms in developing economies, which have weak institutional environments. Obviously, financing is a challenge for firms of all sizes. However, in a context of weak institutional structures and high levels of information opaqueness (Berger and Udell 1998), MSMEs in weak institutional environment face more constraints in relation to liquidity and bank financing (Baas and Schrooten 2006; Coricelli and Frigerio 2019). Our multi-national study provides valuable policy recommendations for the developing economies investigated and, potentially, for other countries as well.

Third, we use a multidimensional construct of a proxy for firm environmental performance. This proxy provides a broader perspective of environmental activities in unlisted firms. This differs from earlier works measuring environmental performance via Kinder, Lydenberg, and Domini's (KLD's) index (Goss and Roberts 2011; Nandy and Lodh 2012) or the ASEET4 index (Cheng et al. 2014; Cheung 2016), both of which use only one variable of corporate environmental performance. Given that environmental performance is multidimensional (Dragomir 2012), studies using these approaches, we believe, fail to capture the full picture In contrast, our 10-factor environmental performance index considers many aspects of corporate environmental activities, which increases the robustness of our findings.

The paper is organised as follows. Section 2 describes the impact of the COVID-19 pandemic on MSMEs. Section 3 describes the data and variables, and Section 4 explains the model specifications. Section 5 discusses our empirical findings, and Section 6 reports on our robustness studies, while Section 7 provides a conclusion.

${ }^{[1]}$ https://covid19.who.int/

${ }^{[2]}$ https://ec.europa.eu/eurostat/documents/2995521/10294864/2-15052020-AP-EN.pdf/5a7ea909-e708-f3d3-8375-e2510298e1b8

${ }^{[3]}$ The definition of MSME varies across countries. The three common denominators are the number of employees, turnover and assets. In this paper, we adopt the SME definition used in the World Bank Enterprise surveys. The employment criterion and categories of firms are as follows: micro constitutes fewer than 5 employees; small constitutes 5-19 employees; medium-sized constitutes 20-99 employees; and large constitutes more than 100 employees.

${ }^{[4]}$ http://www.oecd.org/coronavirus/policy-responses/coronavirus-covid-19-sme-policy-responses-04440101/

${ }^{[5]}$ The literature provides scant evidence of the impact of the financial crisis on the relationship between firm social performance and firm risk (Bouslah et al. 2018) and between social capital and firm performance (Lins et al. 2017, 2019).

${ }^{[6]}$ Recent literature has started to report on developing economies (Féres and Reynaud 2012; García-Rodríguez et al. 2013).

\section{Impact Of The Covid-19 Pandemic On The Msme Sector}

MSMEs account for approximately $90 \%$ of businesses across the world and are responsible for about $50 \%$ of employment ${ }^{[7]}$. MSMEs therefore play a significant role in the economy and are considered as engines of economic growth (Wellalage and Fernandez 2019). COVID-19 has, however, resulted in dramatic changes in the economic and political environment in most countries, causing economic shocks and placing stress on healthcare systems across the world (Kuckertz et al. 2020). In a bid to contain the spread of the virus, a number of countries have imposed national or regional lockdowns have had devastating repercussion for MSMEs. In turn, based on the responses from over 1,200 MSMEs in 109 countries, International Trade Centre survey indicates that pandemic has affected the $2 / 3$ of the MSMEs interviewed. While MSMEs from all regions have been affected by the COVID-19 pandemic, African MSMEs have been hit hardest (Borino and Rollo 2020). Also, recent study shows that in the United States alone, 3.3 million small businesses closed during the February-March period (Fairlie 2020).

MSMEs are financially fragile and generally have liquidity and profitability problems (Juergensen et al. 2020). MSMEs are more vulnerable because of their ownership structure (Martin et al. 2019), and they generally have lower resilience to external shocks (Juergensen et al., 2020) because of their small size and limited human, financial and technical resources. The financial vulnerability of MSMEs was witnessed during the global financial crisis (GFC) in 2008, which caused a significant decline in demand and financial distress (Cowling et al., 2018). Likewise, the COVID-19 pandemic has severely affected MSMEs but to an

Page 3/18 
even greater extent than the GFC (Baker et al. 2020). The negative impact of COVID-19 on the entrepreneurial financial market is forecasted to have significant and long-lasting damage on small firms (Lerner et al. 2020). In particular, MSMEs must grapple with the effects of the pandemic on supply-related issues, such as logistical challenges owing to labour shortages and reductions in transportation, and on demand-related issues, including a dramatic reduction in demand and revenue. ${ }^{[8]}$

Researchers emphatically speculated that small firm finance may be significantly affected by the COVID-19 pandemic. Also, these shocks have negative impact on all types of entrepreneurial and small business finance including debt finance, venture capital and business angels (Demirguc-Kunt et al. 2020). In particular, Brown and Rocha (2020) suggest that start-ups and small businesses in China witnessed a $60 \%$ decline in equity investments in the first quarter of 2020. In a similar vein, a study examining the UK reports that entrepreneurial finance deals in the first quarter of 2020 are fewer by $30 \%$ than the same quarter in 2019 due to a decrease in seed and early-stage financing (Brown et al. 2020). Although the impacts of the COVID-19 pandemic on small businesses are undoubtedly negative, it has been argued that the small size of such businesses also enable them to explore opportunities during the crisis (Williams and Shepherd 2018). Papadopoulos et al. (2020), for example, suggest that the adoption of digital technology can help SMEs to secure continuity during the crisis. Using the data of 250 SMEs from Greece, Kottika et al. (2020) suggest that, despite unfavourable conditions, $85 \%$ of SMEs survived the pandemic by focusing on productivity, efficiency, downsizing, and new partnerships with suppliers. Within the existing body of research on the impact of the pandemic on small businesses, the question of how corporate environmental performance informs the survival of small businesses during the crisis has been neglected.

${ }^{[7]}$ https://www.worldbank.org/en/topic/smefinance

${ }^{[8]}$ http://www.oecd.org/coronavirus/policy-responses/coronavirus-covid-19-sme-policy-responses-04440101/

\section{Data And Variables}

3.1 Data

To explore the relationship between firm level environmental performance and firm financing during the COVID-19 pandemic, we utilise firm level data from two sources: (i) the Enterprise surveys from the World Bank (see http://www.enterprisesurveys.org); and (ii) COVID-19 follow up surveys from the World Bank (see https://www.enterprisesurveys.org/en/covid-19). Enterprise surveys from the World Bank encompass a representative random sample of firms with data collected across the world by using the same core questionnaire and the same sampling method. Face to face interviews are held with the owner/manager or representative. Surveys provide firm level information about unlisted firms of all sizes, such as firm characteristics and owner/manager demographics. This survey also reports information about the firm's access to finance, corruption and crimes, competition and infrastructure. The 2019 Entreprises Surveys provide a green economy module which contains information about environment-related aspects of the sampled firms.

As part of the overall response of the Development Economics Vice Presidency (DEC) of the World Bank, the Enterprise Analysis Unit has been developing different approaches to measure the impact of coronavirus on the private sector. In addition to conducting Enterprise Surveys, phone interviews were held in seven Eastern European and Central Asian countries. The Enterprise Surveys team has now released data pertaining to Albania, Cyprus, Georgia, Greece, Italy, Moldova and the Russian Federation. Enterprise Surveys follow-up surveys data aimed at measuring the impact of the COVID-19 pandemic on businesses ${ }^{[0]}$ which includes follow-up surveys that aim to measure the impact of COVID-19 on businesses by collecting information about closures. The Enterprise Surveys team has similar surveys planned or under implementation in 39 countries.

Our study merges two datasets using unique firm identifications. Our sample includes micro, small and medium firms from 22 sub-industries. From the survey data, our study sample provides information about 3,356 unlisted firms. The number of respondent firms by firm size, the country combination and industry distribution are reported in Table 1.

Table 1 Sample firms 


\begin{tabular}{|c|c|c|c|c|c|c|c|c|c|}
\hline $\begin{array}{l}\text { Country } \\
\text { name }\end{array}$ & $\begin{array}{l}\text { Sample } \\
\text { size }\end{array}$ & $\begin{array}{l}\text { Micro \& } \\
\text { Small }\end{array}$ & Medium & Manufacturing & Retail & Services & Industry & $\begin{array}{l}\text { Number of } \\
\text { firms }\end{array}$ & $\begin{array}{l}\text { Percentage of } \\
\text { firms }\end{array}$ \\
\hline Albania & 277 & 167 & 110 & 146 & 77 & 154 & Manufacturing & & \\
\hline Cyprus & 312 & 201 & 111 & 121 & 92 & 147 & Food & 379 & $12.96 \%$ \\
\hline Georgia & 496 & 286 & 210 & 203 & 123 & 255 & Textiles & 31 & $1.06 \%$ \\
\hline Greece & 466 & 272 & 194 & 315 & 130 & 155 & Garments & 158 & $5.40 \%$ \\
\hline Italy & 586 & 354 & 232 & 461 & 127 & 172 & Chemicals & 31 & $1.06 \%$ \\
\hline Moldova & 286 & 146 & 140 & 134 & 113 & 113 & Plastic \& rubber & 57 & $1.95 \%$ \\
\hline Russia & 933 & 511 & 422 & 889 & 152 & 282 & $\begin{array}{l}\text { Non-metallic mineral } \\
\text { products }\end{array}$ & 120 & $4.10 \%$ \\
\hline Total & 3,356 & 1,937 & 1,419 & 2,269 & 814 & 1,278 & Basic metals & 31 & $1.06 \%$ \\
\hline \multirow[t]{13}{*}{ Percentage } & & $44.42 \%$ & $32.54 \%$ & $52.03 \%$ & $18.67 \%$ & $29.31 \%$ & $\begin{array}{l}\text { Fabricated metal } \\
\text { products }\end{array}$ & 262 & $8.96 \%$ \\
\hline & & & & & & & $\begin{array}{l}\text { Machinery and } \\
\text { equipment }\end{array}$ & 162 & $5.54 \%$ \\
\hline & & & & & & & Electronics & 33 & $1.13 \%$ \\
\hline & & & & & & & Other manufacturing & 1 & $0.03 \%$ \\
\hline & & & & & & & Services & & \\
\hline & & & & & & & Retail & 663 & $22.67 \%$ \\
\hline & & & & & & & Wholesales & 338 & $8.24 \%$ \\
\hline & & & & & & & IT & 80 & $2.74 \%$ \\
\hline & & & & & & & Hotel and restaurants & 241 & $8.24 \%$ \\
\hline & & & & & & & Other service & & \\
\hline & & & & & & & $\begin{array}{l}\text { Services of motor } \\
\text { vehicles }\end{array}$ & 81 & $2.77 \%$ \\
\hline & & & & & & & Construction Section & 192 & $6.56 \%$ \\
\hline & & & & & & & Transport Section & 65 & $2.22 \%$ \\
\hline
\end{tabular}

Figure 1 shows the main source that MSMEs have used to deal with cash flow shortages in the outbreak of COVID-19. Figure $1 \mathrm{~A}$ (full sample) indicates that the majority of firms used equity financing (29\%) as the main source to deal with cash flow shortages during the pandemic. However, approximately $28 \%$ of MSMEs do not have access to any financial source to deal with cash flow shortages. These results highlight the financial fragility of many small businesses during the pandemic. About $21 \%$ of MSMEs delayed payments to suppliers and workers in response to cashflow shortfalls and only $17 \%$ of MSMEs accessed bank loans. As with the trend across the full sample, firms from Georgia, Cyprus and Moldova used equity financing to address cash flow shortfalls. However, Figure 1 shows that the majority of MSMEs from Greece, Albania and Russia have no access to a financial source in order to deal with their cash flow shortage.

Table 2 reports the descriptive statistics of the study sample. According to Table 2, about $72 \%$ of the sample firms have experienced a decrease in liquidity during the pandemic. This is aligned with recent OECD findings, which report that the risk of liquidity shortage is high for a significant portion of firms in OECD countries and that, if quarantine measures last beyond seven months, more than $50 \%$ of firms would face a shortfall of cash (OECD 2020). Studies from developed countries show that approximately half of all small firms have temporarily stopped trading since movement restrictions have been enforced and $60 \%$ of SMEs are at risk of running out of cash reserves (Bartik et al. 2020; Cowling et al. 2018). Table 2 shows that only $17 \%$ of firms in our sample used banks to deal with cash flow shortages, which means approximately $83 \%$ of firms have not borrowed funds from commercial banks. Three percent of firms filed for bankruptcy/insolvency during the pandemic and, while this figure may appear small, the high liquidity shortfall in $72 \%$ of firms may soon turn into a solvency crisis. An ongoing reduction in liquidity and revenues over a prolonged period, coupled with limited sources to deal with this shortfall, push many SMEs to voluntary closure and bankruptcies in the long run.

The mean environmental performance score for the full sample is 1.4, which ranges from 0 (lowest) to 10 (highest). The low mean value of the environmental performance index (EPI) indicates that SMEs are not highly engaged with environmental performance activities. About $34 \%$ of firms have at least one female owner. The average percentage of SMEs that are family-owned is $43 \%$, but it varies from $0 \%$ (non-family owned firms) to $100 \%$ (fully family-owned firms). The average firm age is 18 years, but it varies from 1 year to 199 years. Approximately $58 \%$ of sample firms are micro and small, and $42 \%$ are medium. In terms of 
firm legal ownership, the majority of firms are a company (68\%). Just over a quarter of firms are exporters (26\%). The majority of firms come from the manufacturing industry (46\%), followed by services (32\%) and other services (21\%).

Table 2 Descriptive statistics

\begin{tabular}{|lcllll|}
\hline Variable & Obs & Mean & Std. Dev & Min & Max \\
\hline Liquidity_Dec & 2,651 & 0.7197 & 0.4492 & 0 & 1 \\
\hline Bank & 1,800 & 0.1683 & 0.3742 & 0 & 1 \\
\hline Bankruptcy & 2,655 & 0.0301 & 0.1709 & 0 & 1 \\
\hline EPI & 3,356 & 1.397 & 1.278 & 0 & 10 \\
\hline Female_Own & 3,334 & 0.3437 & 0.4750 & 0 & 1 \\
\hline Family_Own & 3,330 & 42.54 & 47.26 & 0 & 100 \\
\hline Firm_Age & 3,343 & 18.16 & 15.44 & 1 & 196 \\
\hline Small & 3,356 & 0.5771 & 0.4940 & 0 & 1 \\
\hline Medium & 3,356 & 0.4228 & 0.4940 & 0 & 1 \\
\hline Sole_Prop & 3,352 & 0.0945 & 0.2926 & 0 & 1 \\
\hline Partnership & 3,352 & 0.2273 & 0.4191 & 0 & 1 \\
\hline Company & 3,352 & 0.6781 & 0.4672 & 0 & 1 \\
\hline Foreign_Own\% & 3,331 & 3.12 & 16.35 & 0 & 100 \\
\hline Mgr_Exp & 3,300 & 19.80 & 11.86 & 1 & 70 \\
\hline Export\% & 3,324 & 0.0968 & 0.2320 & 0 & 1 \\
\hline Innovation & 3,334 & 0.1304 & 0.3368 & 0 & 1 \\
\hline Bribes & 2,980 & 0.0587 & 0.2351 & 0 & 1 \\
\hline Manufacturing & 3,356 & 0.4636 & 0.4987 & 0 & 1 \\
\hline Services & 3,356 & 0.2115 & 0.4084 & 0 & 1 \\
\hline Other service & 3,356 & 0.3247 & 0.4683 & 0 & 1 \\
\hline
\end{tabular}

\subsection{Variables}

\subsubsection{Dependent variables}

We use three dependent variables related to firm financial situations.

Liquidity_Dec: This variable takes the value of one if firm liquidity decreased during the COVID-19 pandemic. Firm level liquidity is an important factor which determines a firm's ability to pay its creditors and remain solvent in the short run. Liquidity is more of a strategic concept related to MSMEs (Kontuš and Mihanović 2019). A healthy liquidity level is an indicator of the creditworthiness of small firms and improves their borrowing ability.

Bank: This variable takes the value of one if the firm has used commercial banks as the main mechanism for dealing with cash flow shortages during the COVID-19 pandemic.

Bankruptcy: This variable takes the value of one if the firm filed for insolvency or bankruptcy during the pandemic.

\subsubsection{Explanatory variables}

We created a composite index in order to establish a proxy for firm level environmental performance indicators in our regression analyses. This method was initially developed by Jaggi and Freedman (1992) in the adaptation used by Wagner (2005). Following Wagner and Schaltegger (2004), we measure environmental sustainability activities in terms of an index that assesses the reduction of environmental impacts by firms in several categories, each measured by a separate item variable. For each of the items, the Enterprise Survey questionnaire had asked about the series of environmental activities that were undertaken to reduce the company's environmental impact. The following ten questions were used to create the index value: 
(i) Heating and cooling improvements, (ii)More climate-friendly energy generation on-site, (iii) Machinery and equipment upgrades, (iv) Energy management, (v) Waste minimisation, recycling and waste management, (vi) Air pollution control measures, (vii) Water management, (viii) Upgrades of vehicles, (ix) Improvements to lighting systems, $(x)$ Other pollution control measures.

A high score on the index indicates environmental performance above the mean, i.e. a firm that is highly engaged in environmentally sustainable practices. There are no universally accepted standards or methodologies for assessing a firm's environmentally sustainable performance (Ameer and Othman 2012). Consequently, there is no quantitative data available for the environmental performance of unlisted firms. As such, we can argue that measurement of environmental performance needs to be included as a component of firm performance proxies because environmental performance is a holistic view of the effects of environmental management. Following prior literature, we use self-assessment by firms as the most suitable approach for establishing a proxy for environmental performance (Sharma 2001; Wagner and Schaltegger 2004). The responses yielded from the ten questions posed about the firm's environmental activities provide the basis for our measurement of environmental performance.

Earlier studies adopted several methods to ascertain corporate environmental performance, including external audits, external awards or accreditation processes, indices, and non-quantifiable sustainability initiatives. Such variation leads to inconsistency of environmental performance variables utilised in empirical studies (Braam et al. 2016). Recent financial studies have used environmental, social, and governance performance scores obtained from the Thomson Reuters ASSET4 index as a reliable proxy for environmental performance for large listed firms (Cheng et al. 2014). ASSET4 includes data about the energy used by a firm, water and waste recycling practices, carbon emissions, and spills and pollution controversies. Due to data unavailability, we cannot apply the ASSET4 index to the unlisted firms we sampled. Moreover, our proxy incorporates ten indicators, which better represent the environmental activities of unlisted firms. It should be noted that our index is output-oriented, which diverges from other studies which have used environmental performance effort as input measures, (such as the amount of environmental management activities a firm records), as proxies for environmental performance activities. Given that all input efforts do not necessarily equate to the production of desired outputs, we contend that our output proxy is more reliable.

One concern with the specifications in our regression models is that the strong performance of high environmental performance firms during the COVID-19 pandemic may be due to omitted variables that happen to be correlated with EPI, and not due to environmental performance itself. To address this issue, we include several control variables. The control variables chosen for the analysis are widely recognised in the literature as those that affect firm level financing. First, we control for a firm's financial health in the year before the COVID-19 pandemic on the basis that firms with high financial stability before the pandemic may have a greater ability to withstand a downturn in the economy. Therefore, we include: Credit_Constraint (constraints as value one if the firm does not have (i) an overdraft facility or (ii) a line of credit or loan from a financial institution and zero otherwise) and Finance_Obstacle (obstacle as value one if the firm reports that access to finance is a major or very severe obstacle to the current operations of the firm and zero otherwise) as a proxy for the financial health of the firm prior to the outbreak of COVID-19.

Additional firm characteristics may also be important for firm level financing. As a proxy for firm size, we use two categorical variables based on numbers of employees, such as Micro \& Small and Medium. We also included firm age. The following proxies indicate the ownership characteristics of the firm: the legal entity of the firm - sole proprietorship, partnership and company; and the percentage of foreign ownership, family ownership and female ownership. Export and innovation status of the firm, top manager experience in the field, and firm level bribes payment were also variables included in our regression.

Moreover, we control for the overall financial situation at country- by using the depth of credit information index (Credit_Index), the ease of doing business index (Ease_Business) and the percentage of firms using banks to finance working capital (Bank_Capital). To address possible valuation differences among industries, we included industry dummies.

Table A1 in the Appendix presents definitions and metrics for the variables of this study.

${ }^{[9]}$ The Enterprise Survey also provided Armenian data, but this was excluded from our study as it contains only micro firms.

\section{Method}

To analyse the relationship between the financing of MSMEs and environmental performance, we employ a probit model, where our outcome variable(s) is binary. That is, we assume:

$$
\operatorname{Probit}\left(Y_{i c}=1\right)=\alpha_{c}+\left(\alpha+\beta E P I_{i c}+\gamma X_{i c}+\mu Y_{i c}+\varepsilon_{i c}\right)
$$

SME financing is captured by three binary variables. The first is a Liquidity_Dec which takes a value of one if the firms report that the COVID-19 outbreak decreased firm liquidity/cashflow, and zero otherwise. The second variable is Bank which takes the value of one if the firm received loans from commercial banks to deal with cash flow shortages during the COVID-19 outbreaks, and zero otherwise. The third variable is bankruptcy which takes the value of one if the firm filed for insolvency or bankruptcy during the pandemic, and zero otherwise.

The main explanatory variable, EPI, is a continuous variable that ranges from zero to ten, with the value zero being for firms which have no engagement with environmental performance activities. Vector $X$ captures firm characteristics and ownership characteristics, such as firm financial stability proxies, percentage of family ownership, firm age, firm size, firm legal ownership status, innovations, and export status. Vector $Y$ captures institutional characterises, such as Credit_Info, Doing_Business and Bank_Cap. 
We cluster the standard errors by country, where vce (cluster country) accommodates and adjusts for the correlation of observations within values of the country. Observations from the same country are likely to be more similar, therefore, the country-level cluster approach is appropriate.

\section{Results}

5.1 Firm level environmental performance and financing in the COVID-19 outbreak

The base results of the effect of environmental performance on liquidity decrease, bank credit approval, and insolvency/bankruptcy, are presented in columns I, II and III in Table 3 respectively. In each column, we report probit regression results and marginal effects.

Our results in column I show that the environmental performance of a firm is significantly negatively correlated with liquidity decrease. In particular, the marginal effects show that for every one unit increase in the EPI index, the probability of liquidity shortfall decreases by 0.0172 . Although the results in column II show that the environmental performance of a firm is positively correlated with bank financing access during the pandemic, the relationship is insignificant. Interestingly, our results in column III show that the environmental performance of a firm is significantly negatively correlated with the probability of MSMEs' insolvency/bankruptcy during the pandemic. In particular, the marginal effects show that for every one unit increase in the EPI index, the probability of bankruptcy/insolvency decreases by 0.0077 . Our results suggest that the trust between firms and stakeholders built through investment in firm level environmental activities pays off when markets suffer from a negative shock. In sum, firms with greater environmental performance create value and cooperation from stakeholders that leads to an increase in firm cash flow, access to bank financing, and solvency. This may be because proactive environmental practices are exposed to a low degree of risk (Godfrey et al. 2009; Muhammad et al. 2015a), and easier access to the financial market (Jo and $\mathrm{Na}$ 2012). It may also be that CSR and environmental activities restore stakeholder trust after the crisis (PricewaterhouseCoopers 2013). Overall, our finding is in line with Lins et al. (2017) and Lins et al. (2019) who find that the firms with high CSR initiatives experience higher profitability, growth, sales and access to funds during the financial crisis of 2008-2009.

Table 3 Probit and marginal probit results of firm financing and environmental performance in COVID-19 outbreak 


\begin{tabular}{|c|c|c|c|c|c|c|}
\hline & $\begin{array}{l}\text { Liquidity__Dec } \\
\text { (I) }\end{array}$ & & $\begin{array}{l}\text { Bank } \\
\text { (II) }\end{array}$ & & $\begin{array}{l}\text { Bankruptcy } \\
\text { (III) }\end{array}$ & \\
\hline Variable & Probit & Marginal & Probit & Marginal & Probit & Marginal \\
\hline \multirow[t]{2}{*}{ EPI } & $-.0521^{\star}$ & $-.0172^{\star}$ & .0351 & .0088 & $-.1130 * *$ & $-.0069 *$ \\
\hline & $(.0204)$ & $(.0067)$ & $(.0267)$ & $(.0064)$ & $(.0662)$ & $(.0042)$ \\
\hline \multirow[t]{2}{*}{ Female_Own } & .0838 & .0277 & $.1512^{\star \star \star}$ & 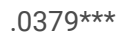 & -.1416 ** & $-.0141 * \star$ \\
\hline & $(.0651)$ & $(.0212)$ & $(.0567)$ & $(.0127)$ & $(.0621)$ & $(.0047)$ \\
\hline \multirow[t]{2}{*}{ Family_Own } & -.0004 & -.0001 & .0020 & .0005 & .0001 & $5.3 e-06$ \\
\hline & $(.0005)$ & $(.0002)$ & $(.0014)$ & $(.0003)$ & $(.0018)$ & $(.0001)$ \\
\hline \multirow[t]{2}{*}{ Firm_Age } & $-.0042^{\star}$ & $-.0014 *$ & $-.0051 \star \star$ & $-.0013^{\star \star}$ & .0017 & -.0002 \\
\hline & $(.0026)$ & $(.0008)$ & $(.0023)$ & $(.0006)$ & $(.0024)$ & $(.0001)$ \\
\hline \multirow[t]{2}{*}{${ }^{ \pm}$Medium } & $.2801^{\star \star}$ & $.0925^{\star *}$ & .0257 & .0064 & .0300 & .0018 \\
\hline & $(.1004)$ & $(.0342)$ & $(.0711)$ & $(.0178)$ & $(.1718)$ & $(.0104)$ \\
\hline \multirow[t]{2}{*}{${ }^{\infty}$ Partnership } & $-.1800 * *$ & $-.0596^{\star \star}$ & -.2125 & -.0104 & -.2648 & $-.0232^{\star \star}$ \\
\hline & $(.0931)$ & $(.0302)$ & $(.1655)$ & $(.0214)$ & $(.2457)$ & $(.0126)$ \\
\hline \multirow[t]{2}{*}{${ }^{\infty}$ Company } & -.1110 & -.0368 & -.0418 & -.0532 & $-.3452^{\star \star}$ & $-.0252^{\star \star \star}$ \\
\hline & $(.0776)$ & $(.0260)$ & $(.0850)$ & $(.0413)$ & $(.1700)$ & $(.0062)$ \\
\hline \multirow[t]{2}{*}{ Foreign_Own\% } & -.0009 & -.0003 & -.0009 & -.0002 & - & - \\
\hline & $(.0024)$ & $(.0008)$ & $(.0022)$ & $(.0005)$ & & \\
\hline \multirow[t]{2}{*}{ Mgr_Exp } & -.0005 & -.0002 & $.0042^{\star \star}$ & $.0011^{\star \star}$ & .0084 & 0005 \\
\hline & $(.0024)$ & $(.0008)$ & $(.0023)$ & $(.0005)$ & $(.0057)$ & $(.0003)$ \\
\hline \multirow[t]{2}{*}{ Exporter } & .0002 & .0001 & -.0005 & -.0001 & .0012 & .0001 \\
\hline & $(.0014)$ & $(0004)$ & $(.0020)$ & $(.0005)$ & $(.0025)$ & $(.0002)$ \\
\hline \multirow[t]{2}{*}{ Innovation } & -.0295 & -.0098 & .0429 & .0107 & .0667 & .0041 \\
\hline & $(.0041)$ & $(.0145)$ & $(.0874)$ & $(.0224)$ & $(.1542)$ & $(.0095)$ \\
\hline \multirow[t]{2}{*}{ Bribes } & .0198 & .0065 & .0156 & .0039 & .1656 & .0101 \\
\hline & $(.0856)$ & $(.0283)$ & $(.0942)$ & $(.0486)$ & $(.1329)$ & $(.0085)$ \\
\hline \multirow[t]{2}{*}{ Credit_Constraint } & .0121 & .0013 & $-.1335^{\star \star \star}$ & $-.0582^{\star \star \star}$ & 0024 & 0002 \\
\hline & $(.0591)$ & $(.0008)$ & $(.0191)$ & $(.02641)$ & $(.0001)$ & $(.0012)$ \\
\hline \multirow[t]{2}{*}{ Finance_Obstacle } & $.7180^{\star}$ & $.5717 *$ & -.3846 & -.0034 & -.0096 & .0026 \\
\hline & $(.2230)$ & $(.0091)$ & $(.0707)$ & $(.0035)$ & $(.0042)$ & $(.0185)$ \\
\hline \multirow[t]{2}{*}{ Credit_info } & $-.1124^{\star \star \star}$ & -.1511 & .0121 & -.0379 & .0042 & .0014 \\
\hline & $(.0274)$ & $(.1530)$ & $(.0227)$ & $(.0372)$ & $(.0629)$ & $(.0208)$ \\
\hline \multirow[t]{2}{*}{ Doing_business } & .0647 & .0162 & $-.3402^{\star \star}$ & $-.1124^{\star}$ & $-.3444^{\star}$ & $-.1141^{\star}$ \\
\hline & $(.1060)$ & $(.0266)$ & $(.0757)$ & $(.0274)$ & $(.0828)$ & $(.0298)$ \\
\hline \multirow[t]{2}{*}{ Bank_cap } & $.2606^{*}$ & .0159 & .0762 & .0046 & .0366 & .0121 \\
\hline & $(.1544)$ & $(.0096)$ & $(.2419)$ & $(.0148)$ & $(.0685)$ & $(.0227)$ \\
\hline Industry dummies & Yes & Yes & Yes & Yes & Yes & Yes \\
\hline \multirow[t]{2}{*}{ Cons } & $.5614^{\star \star \star}$ & & $-1.081^{* \star \star}$ & & $-1.631 * \star \star$ & \\
\hline & $(.0885)$ & & $(.2278)$ & & $(.2024)$ & \\
\hline Log pseudolikelihood & -1298.7315 & & -693.02 & & -287.41 & \\
\hline Observations & 2264 & 2,264 & 1,536 & 1,536 & 2,175 & 2,444 \\
\hline
\end{tabular}

Note: Table 3 reports probit results and marginal effects estimated around means points. Robust standards errors are reported in parentheses. \pm Omitted firm size is Micro \& Small. ${ }^{\infty}$ Omitted firm legal status is soleproperitership. *Significant at $10 \%$ level, **Significant at $5 \%$ level, ***Significant at $1 \%$ level. 
5.2 Sensitive industries, environmental performance activities, and financing during COVID-19 outbreak.

Firms from all industries have been impacted from COVID-19 outbreak. Nevertheless, the hospitality and retail industries are faced with the most significant disruption in recent global pandemic (Orr 2020). In this section, we investigate whether the positive effect of environmental performance is outperforming in sensitive industries.

Table 4 indicates that the firms with high environmental performance in sensitive industries exhibit superior performance during the pandemic. The coefficient on the EPI is negative and significant, indicating that regardless of the industry to which the firm belongs, firm level environmental performance negatively impacts on the probability of cash flow decrease $(\beta=-0.0082)$ and bankruptcy $(\beta=-0.0059)$. The significant and negative relationship is shown in the interaction variable (EPIX i. Sensitive_industry), firm level liquidity decrease $(\beta=-0.0082+(-0.0154)=-0.0236)$ and bankruptcy $(\beta=-0.0059+(-0.0038)=-$ 0.0097). The results show that the environmental performance effect is more pronounced in sensitive industries than in non-sensitive industries.

Table 4 Highly sensitive industries, environmental performance activities, and financing in COVID-19 outbreak

\begin{tabular}{|c|c|c|c|c|c|c|}
\hline & \multicolumn{2}{|c|}{$\begin{array}{l}\text { Liquidity_Dec } \\
\text { (I) }\end{array}$} & \multicolumn{2}{|l|}{$\begin{array}{l}\text { Bank credit } \\
\text { (II) }\end{array}$} & \multicolumn{2}{|c|}{$\begin{array}{l}\text { Bankruptcy } \\
\text { (III) }\end{array}$} \\
\hline Variable & Probit & Marginal & Probit & Marginal & Probit & Marginal \\
\hline \multirow[t]{2}{*}{ EPI } & $-.0248^{\star \star \star}$ & $.0082^{\star \star \star}$ & .0187 & .0047 & $-.0960 \star \star$ & $-.0059 *$ \\
\hline & $(.0302)$ & $(.0099)$ & $(.0356)$ & $(.0089)$ & $(.0886)$ & $(.0058)$ \\
\hline \multirow[t]{2}{*}{ Sensitive_industry } & $-.1657^{\star \star \star}$ & $-.0550 \star \star$ & -.1402 & -.0352 & -.0245 & -.0015 \\
\hline & $(.2367)$ & $(.0793)$ & $(.1329)$ & $(.0329)$ & $(.2109)$ & $(.0131)$ \\
\hline \multirow[t]{2}{*}{ EPI* Sensitve_industry } & $-.0465^{\star \star \star}$ & $-.0154^{\star \star}$ & .0291 & .0073 & $-.0626 * \star \star$ & $-.0038^{\star * *}$ \\
\hline & $(.0680)$ & $(.0227)$ & $(.0395)$ & $(.0097)$ & $(.1320)$ & $(.0079)$ \\
\hline Control variables & Yes & Yes & Yes & Yes & Yes & Yes \\
\hline \multirow[t]{2}{*}{ Cons } & $.8078^{* \star *}$ & & $-1.000 * \star \star *$ & & $-1.477^{* * *}$ & \\
\hline & $(.1394)$ & & $(.1710)$ & & $(.1032)$ & \\
\hline Log pseudolikelihood & -1320.5 & & -694.40 & & -289.18 & \\
\hline Observations & 2,264 & 2,264 & 1,536 & 1,536 & 2,175 & 2,175 \\
\hline
\end{tabular}

Note: Table 4 reports probit results and marginal effects estimated around means points. Robust standards errors are reported in parentheses. \pm Omitted firm size is Micro \& Small. ${ }^{\infty}$ Omitted firm legal status is soleproperitership. *Significant at $10 \%$ level, $* \star$ Significant at $5 \%$ level, $* \star \star S i g n i f i c a n t$ at $1 \%$ level.

\section{Robustness}

This study runs a series of tests to ensure the robustness of baseline results.

\subsection{Propensity score matching method}

The probit model tested firm level financing as a function of firm level environmental performance. However, the results will be biased when an endogeneity issue is present. In empirical research, the propensity score matching (PSM) technique heavily draws on causal inferences by using observational data (Wellalage and Locke 2020). PSM controls causal interferences and self-selection biases by placing them into non-random treatment (Rosenbaum and Rubin 1983). Our focus was the comparison between the propensity for financing during the COVID-19 pandemic in firms that are exposed to no treatment $T=0$ (EPI index is less than average EPI of the sample) and the propensity for innovation in firms that are exposed to treatment $T=1$ (EPI index is above average EPI of the sample). We use three matching methods: nearest neighbour matching, kernel matching, and stratification matching. To further ensure the efficiency of PSM, we conduct a covariate balance analysis on the mean difference in the covariate used in the probit model between the treatment group and the control group. The unreported results of the covariate balance indicate the difference between the treatment group and control groups are small across all variables, confirming that our PSM is appropriate.

Table 5 includes all three matching models and shows that ATT is statistically significant and negative for cash flow decrease and bankruptcy. In particular, the estimated negative average effect of EPI on liquidity decrease and liquidation for firms that have high EPI is between $3 \%$ to $3.5 \%$, and between $1.4 \%$ and $1.5 \%$, respectively. Overall, these findings are consistent with our main findings which support the view that, in every sense of the phrase, it "pays to be green".

Table 5 The impact of environmental performance on financing: propensity score matching (PSM). 


\begin{tabular}{|c|c|c|c|c|c|c|c|c|c|c|c|c|c|c|c|}
\hline \multirow[t]{2}{*}{ Panel A: } & \multicolumn{5}{|c|}{ Liquidity_Dec } & \multicolumn{5}{|l|}{ Bank } & \multicolumn{5}{|c|}{ Bankruptcy } \\
\hline & $\begin{array}{l}\text { No. } \\
\text { treated }\end{array}$ & $\begin{array}{l}\text { No. } \\
\text { contr. }\end{array}$ & $\mathrm{ATT}^{\mathrm{a}}$ & Std.Err & $\mathrm{t}$ & $\begin{array}{l}\text { No. } \\
\text { treated }\end{array}$ & $\begin{array}{l}\text { No. } \\
\text { contr. }\end{array}$ & $\mathrm{ATT}^{\mathrm{a}}$ & Std.Err & $\mathrm{t}$ & $\begin{array}{l}\text { No. } \\
\text { treated }\end{array}$ & $\begin{array}{l}\text { No. } \\
\text { contr. }\end{array}$ & ATT $^{\mathrm{a}}$ & Std.Err & $\mathrm{t}$ \\
\hline $\begin{array}{l}\text { Nearest } \\
\text { neighbour } \\
\text { matching }\end{array}$ & 1351 & 1201 & -0.035 & 0.017 & 2.058 & 1351 & 809 & 0.011 & 0.015 & 0.728 & 1351 & 1211 & -0.014 & 0.007 & 2.7 \\
\hline $\begin{array}{l}\text { Kernel } \\
\text { matching }\end{array}$ & 1325 & 1528 & -0.035 & 0.020 & 2.771 & 1351 & 1573 & 0.013 & 0.023 & 1.034 & 1351 & 1573 & -0.014 & 0.016 & $2 . \epsilon$ \\
\hline $\begin{array}{l}\text { Stratification } \\
\text { matching }\end{array}$ & 1325 & 1528 & -0.030 & 0.021 & 2.491 & 1351 & 1573 & 0.014 & 0.014 & 0.971 & 1351 & 1573 & -0.015 & 0.006 & 2.2 \\
\hline
\end{tabular}

Notes: ATT stands for the average treatment effect on treated. We included all Baseline model covariates in here

\subsection{Probit model with sample selection}

This study adopts the probit model with sample selection method as a robustness check to control the potential sample selection bias (Heckman 1977). In the first step, we estimate a probit model with a binary dummy as the dependent variable. However, in the sample, a firm is observable when the firm sales decrease. This raises the issue of selection bias. To address selection bias, we use a COVID_Temp_Closed variable in the selection equation which takes the value of one if the firm reports that it temporarily closed as a result of the COVID-19 outbreak, and zero otherwise.

Similarly, when we estimate a probit model with a binary dummy as dependent, a firm is observable when the cash flow/liquidity decreases. To address selection bias, we use proxies for two other types of finance sources, such as government grants (Government_Grant) and credit from non-financial institutions and microfinance institutions (MF).

When we estimate a probit model with a binary dummy as dependent, a firm is observable if the establishment has overdue obligations to any financial institution during the COVID-19 pandemic. To address selection bias, we use proxies for two other types of finance sources: Government_Support, which indicates whether or not the establishment received any national or local government support in response to the crisis, and Snr_Mgr_Time, which indicates the time spent by senior management on dealing with regulations.

Table 6 reports the heckprobit regression results. The marginal effects show that a unit increase in the EPI, on average, leads to a decrease of 0.0079 in the probability of cash flow decrease and 0.0020 in the probability of bankruptcy. Overall, we can see that the EPI is still significantly and negatively correlated with cash flow decrease and bankruptcy, demonstrating that environmental performance enhances firm financing during the pandemic.

Table 6 Heckprobit results of liquidity decrease, bank loan and bankruptcy and environmental performance in COVID-19 outbreak 


\begin{tabular}{|c|c|c|c|c|c|c|}
\hline & $\begin{array}{l}\text { Liquidity_Dec } \\
\text { (I) }\end{array}$ & & $\begin{array}{l}\text { Bank credit } \\
\text { (II) }\end{array}$ & & $\begin{array}{l}\text { Bankruptcy } \\
\text { (III) }\end{array}$ & \\
\hline Variable & heckprobit & Marginal & Probit & Marginal & Probit & Marginal \\
\hline \multirow[t]{2}{*}{ EPI } & $-.1394 *$ & $-.0079 * \star$ & .0390 & .0076 & 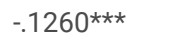 & $-.0020 \star \star$ \\
\hline & $(.0848)$ & $(.0045)$ & $(.0320)$ & $(.0060)$ & $(.1765)$ & $(.2923)$ \\
\hline \multirow[t]{2}{*}{ Female_Own } & .0838 & -.0038 & $.2283^{\star \star}$ & $.0450 * \star$ & -.2894 & -.0046 \\
\hline & $(.0651)$ & $(.0061)$ & $(.0885)$ & $(.0179)$ & $(.3357)$ & $(.6714)$ \\
\hline \multirow[t]{2}{*}{ Family_Own } & -.0005 & -.00002 & $.0024^{\star *}$ & $.0004^{\star \star}$ & -.0007 & -.0001 \\
\hline & $(.0005)$ & $(.00006)$ & $(.0010)$ & $(.0002)$ & $(.0033)$ & $(.0016)$ \\
\hline \multirow[t]{2}{*}{ Firm_Age } & -.0042 & .00002 & -.0042 & -.0008 & -.0001 & $-4.72 \mathrm{e}-07$ \\
\hline & $(.0026)$ & $(.0002)$ & $(.0039)$ & $(.0007)$ & $(.0128)$ & $(0002)$ \\
\hline \multirow[t]{2}{*}{ Medium } & $-.4139 \star \star$ & -.0005 & .0491 & .0096 & $-.3870 * \star$ & -.0034 \\
\hline & $(.0755)$ & $(.2801)$ & $(.0952)$ & $(.0188)$ & $(.2009)$ & $(.0033)$ \\
\hline \multirow[t]{2}{*}{ Partnership } & $-.1800 \star \star$ & -.0016 & $-.3036^{\star \star}$ & $-.0598 * \star$ & $-.7271^{\star \star}$ & -.0117 \\
\hline & $(.0931)$ & $(.0110)$ & $(.1605)$ & $(.0320)$ & $(.4146)$ & $(.1686)$ \\
\hline \multirow[t]{2}{*}{ Company } & -.1110 & .0004 & -.1460 & -.0288 & $-.9246 * *$ & -.0149 \\
\hline & $(.0776)$ & $(.0097)$ & $(.1352)$ & $(.0260)$ & $(.3638)$ & $(.2145)$ \\
\hline \multirow[t]{2}{*}{ Foreign_Own\% } & -.0009 & -.0001 & .0009 & .0001 & -.1605 & -.0026 \\
\hline & $(.0024)$ & $(.0001)$ & $(.0027)$ & $(.0005)$ & $(.1840)$ & $(.0743)$ \\
\hline \multirow[t]{2}{*}{ Mgr_Exp } & -.0078 & -.0004 & .0026 & .0005 & $.0257^{\star \star \star}$ & .0004 \\
\hline & $(.0053)$ & $(.0002)$ & $(.0047)$ & $(.0008)$ & $(.0135)$ & $(.0597)$ \\
\hline \multirow[t]{2}{*}{ Exporter } & .0023 & .0001 & -.0006 & -.0001 & -.0141 & -.0002 \\
\hline & $(.0024)$ & $(.0001)$ & $(.0017)$ & $(.0003)$ & $(.0133)$ & $(.0328)$ \\
\hline \multirow[t]{2}{*}{ Innovation } & -.1106 & -.0062 & -.0037 & -.0007 & -.1626 & -.0026 \\
\hline & $(.1400)$ & $(.0078)$ & $(.1275)$ & $(.0247)$ & $(.4094)$ & $(.03772)$ \\
\hline \multirow[t]{2}{*}{ Bribes } & -.0150 & -.0008 & .0052 & .0010 & .3230 & .0052 \\
\hline & $(.2454)$ & $(.0138)$ & $(.1903)$ & $(.0375)$ & $(.4167)$ & $(.7495)$ \\
\hline \multirow[t]{2}{*}{ Credit_Constraint } & 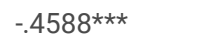 & $-.0234 * \star \star$ & $-.1375^{\star \star}$ & -.0271 & -.7838 & .0083 \\
\hline & $(.1543)$ & $(.2930)$ & $(.2358)$ & $(.0465)$ & $(.3180)$ & $(.0057)$ \\
\hline \multirow[t]{2}{*}{ Finance_Obstacle } & $-.4117 \star \star$ & $-.0260 * \star$ & -.4113 & -.0811 & .0012 & .2944 \\
\hline & $(.3538)$ & $(.0260)$ & $(.0831)$ & $(.0164)$ & $(.0023)$ & $(.1893)$ \\
\hline \multirow[t]{2}{*}{ Credit_info } & $-.3288^{\star}$ & -.0233 & -.6182 & -.1227 & .0662 & -.1482 \\
\hline & $(.3445)$ & $(.0110)$ & (.0109) & $(.0029)$ & $(.1520)$ & $(.1430)$ \\
\hline \multirow[t]{2}{*}{ Doing_business } & -.0079 & -.0018 & -.4111 & -.0812 & .1632 & .3206 \\
\hline & $(.0036)$ & $(.0194)$ & $(.1190)$ & $(.0236)$ & $(.1430)$ & $(.1127)$ \\
\hline \multirow[t]{2}{*}{ Bank_cap } & -.2803 & -.0004 & -.0044 & -.0008 & $-.2296 * \star \star$ & -.0033 \\
\hline & $(.1475)$ & $(.0002)$ & $(.0062)$ & $(.0012)$ & $(.0793)$ & $(.0033)$ \\
\hline Industry dummies & Yes & Yes & Yes & Yes & Yes & Yes \\
\hline \multirow[t]{3}{*}{ Cons } & $2.084^{\star \star \star}$ & & $-1.224 * \star \star$ & & $-1.606^{\star \star \star}$ & \\
\hline & $(.2333)$ & & $(.1700)$ & & $(.1140)$ & \\
\hline & Sales_Decrease & & Cashflow_Decrease & - & Overdue_Obli & - \\
\hline \multirow[t]{2}{*}{ COVID_Temp_Closed } & 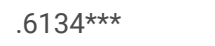 & & & - & - & - \\
\hline & $.0541)$ & & & & & \\
\hline Government_Grant & & & $.6836^{\star \star \star}$ & - & - & - \\
\hline
\end{tabular}

Page 12/18 


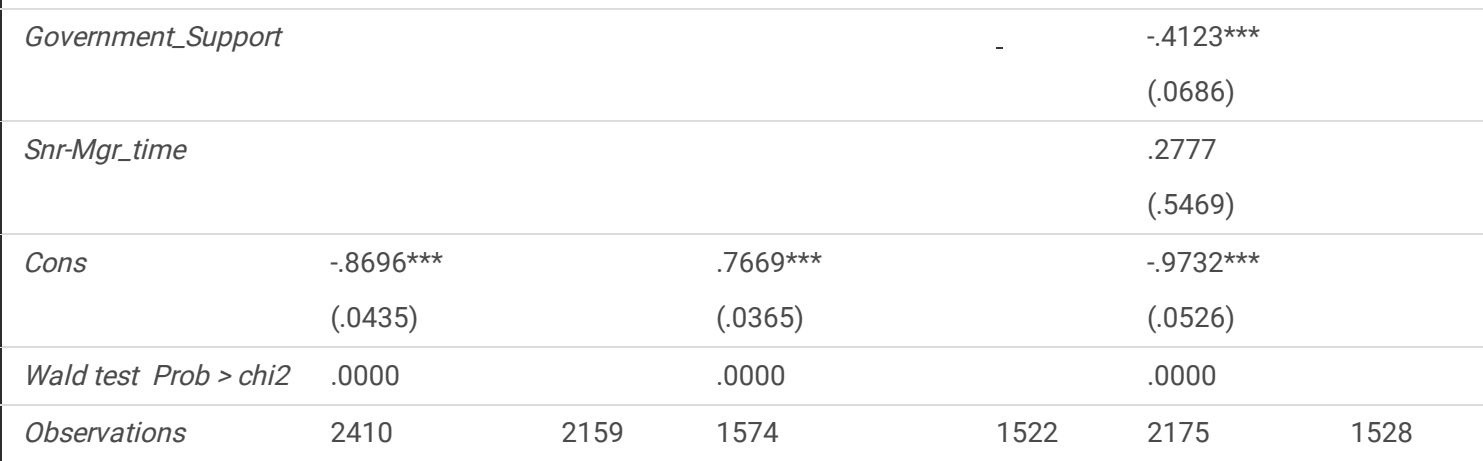

Note: Table 6 reports heckprobit results and marginal effects estimated around means points. Robust standards errors are reported in parentheses. The Need equals one if the firm reports a need for loans, zero otherwise. Apply equals one if the firm applies for a loan, zero otherwise. Loan approval equals one if the firm gets at least one loan, zero otherwise. Collateral equals one if the firm pledge collateral for their approved loan, zero otherwise. Duration equals to one if the firm received long term loan (more than or equal 5 years), zero otherwise. Crime and Sales_Increase are two instrumental variables in "Need" selection equation. Trade_Credit and Informal_Credit are the two instrumental variables in "Apply" selection equation. Internal_funds and Snr_Mgr_Time are the two

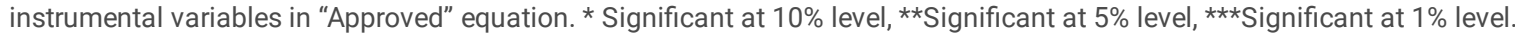

\subsection{Excluded micro firms}

In the third robustness test, we assess whether the decision to remove micro-firms from our sample affects our results. We excluded firms (77 in total) which belong to the micro category. This was on the basis that micro firms have limited access to external financing, and they are mainly financed by the owner/managers, which could outweigh other factors during the pandemic. We re-estimate our baseline model for only small and medium-sized firms and observe that the unreported results align with our baseline model.

\section{Conclusion}

This paper examines the effect of firm environmental performance on firm financing during the COVID-19 pandemic using a sample of unlisted MSMEs. The evidence summarised in the results section indicates that firm level environmental performance reduces liquidity decrease and bankruptcies during the pandemic. Furthermore, our industry analysis indicates that the impact of environmental performance on firm financing is more pronounced in sensitive industries (hospitality and retail) than in non-sensitive industries. Overall, our results are consistent with our conjecture that a firms' environmental performance can limit the negative effects when markets and institutions suffer a negative shock.

Worldwide, MSMEs make up more than $95 \%$ of all firms, when both formal and informal businesses are considered. Therefore, a widespread collapse of MSMEs could have a significant negative impact on global economy. In their response to the COVID-19 pandemic, governments should prioritize policies that support MSMEs. Our study leads to several policy implications. First, it highlights the importance of environmental activities as a business strategy that is integrated with core business objectives to manage firm level financing. We illustrate that firm-specific environmental performance can be thought of as an insurance policy for firms that, quite literally, pays off when the overall economy experiences a negative shock. We also highlight the importance of favourable monetary policies, such as support programmes and the provision of short-term credit to the private sector, which work to generate a continued flow of credit to businesses and to cushion the financial distress on solvent private firms.

As with all environmental performance measures used in prior studies, we cannot fully rule out the possibility that our environmental performance index suffers measurement errors. To alleviate this concern, we suggest that a much broader framework should be considered in future studies. The current lack of a widely accepted framework for measuring the proxy for environmental performance may limit opportunities to compare the environmental performance of different firms. Therefore, future studies can consider working towards a universal proxy for environmental performance in order to facilitate comparative studies.

\section{Declarations}

Funding This research did not receive any specific grants or funding.

Conflicts of interest/Competing interests There are no conflicts to declare.

Availability of data and material Data is available on request from the corresponding author.

Code availability Codes are available on request from the corresponding author.

\section{References}


Ameer, R., \& Othman, R. (2012). Sustainability practices and corporate financial performance: A study based on the top global corporations. Journal of Business Ethics, 108(1), 61-79, doi:10.1007/s10551-011-1063-y.

Baas, T., \& Schrooten, M. (2006). Relationship banking and SMEs: A theoretical analysis. Small Business Economics, 27(2-3), 127-137.

Baker, S., Bloom, N., Davis, S., \& Terry, S. (2020). Covid-induced economic uncertainty (No. w26983). National Bureau of Economic Research.

Banerjee, R., Gupta, K., \& Mclver, R. (2019). What matters most to firm-level environmentally sustainable practices: Firm-specific or country-level factors? Journal of Cleaner Production, 218, 225-240, doi:10.1016/j.jclepro.2019.02.008.

Bartik, A. W., Bertrand, M., Cullen, Z. B., Glaeser, E. L., Luca, M., \& Stanton, C. T. (2020). How are small businesses adjusting to covid-19? early evidence from a survey. National Bureau of Economic Research.

Bauer, R., \& Hann, D. (2010). Corporate environmental management and credit risk.

Beck, T., \& Demirguc-Kunt, A. (2006). Small and medium-size enterprises: Access to finance as a growth constraint. Journal of Banking \& Finance, 30(11), 2931-2943.

Berger, A. N., \& Udell, G. F. (1998). The economics of small business finance: The roles of private equity and debt markets in the financial growth cycle. Journal of Banking \& Finance, 22(6-8), 613-673.

Borino, F., \& Rollo, V. (2020). Quantifying the effect of COVID-19 on small business around the world. (Vol. 2020): International Trade Centre.

Bouslah, K., Kryzanowski, L., \& M'Zali, B. (2018). Social performance and firm risk: impact of the financial crisis. Journal of Business Ethics, $149(3)$, 643-669.

Braam, G. J., de Weerd, L. U., Hauck, M., \& Huijbregts, M. A. (2016). Determinants of corporate environmental reporting: The importance of environmental performance and assurance. Journal of Cleaner Production, 129, 724-734.

Bragdon, J., \& Marlin, J. (1972). Is Pollution Profitable? Risk Management, 19, 9-18.

Branco, M. C., \& Rodrigues, L. L. (2006). Corporate social responsibility and resource-based perspectives. Journal of Business Ethics, 69(2), $111-132$.

Brown, R., \& Rocha, A. (2020). Entrepreneurial uncertainty during the Covid-19 crisis: Mapping the temporal dynamics of entrepreneurial finance. Journal of Business Venturing Insights, 14, e00174.

Brown, R., Rocha, A., \& Cowling, M. (2020). Financing entrepreneurship in times of crisis: Exploring the impact of COVID-19 on the market for entrepreneurial finance in the United Kingdom. International Small Business Journal, 38(5), 380-390.

Cheng, B., loannou, I., \& Serafeim, G. (2014). Corporate social responsibility and access to finance. Strategic management journal, 35(1), 1-23, doi:10.1002/smj.2131.

Cheung, A. (2016). Corporate social responsibility and corporate cash holdings. Journal of Corporate Finance, --, doi:10.1016/j.jcorpfin.2016.01.008.

Coricelli, F., \& Frigerio, M. (2019). Interenterprise credit and adjustment during financial crises: the role of firm size. Journal of Money, Credit and Banking, 51(6), $1547-1580$.

Cowling, M., Liu, W., \& Zhang, N. (2018). Did firm age, experience, and access to finance count? SME performance after the global financial crisis. Journal of Evolutionary Economics, 28(1), 77-100.

Demirguc-Kunt, A., Lokshin, M., \& Torre, I. (2020). The sooner, the better: The early economic impact of non-pharmaceutical interventions during the COVID-19 pandemic. World Bank Policy Research Working Paper(9257).

Dragomir, V. D. (2012). The disclosure of industrial greenhouse gas emissions: a critical assessment of corporate sustainability reports. Journal of Cleaner Production, 29, 222-237.

Fairlie, R. W. (2020). The Impact of Covid-19 on Small Business Owners: Evidence of Early-Stage Losses from the April 2020 Current Population Survey. National Bureau of Economic Research.

Féres, J., \& Reynaud, A. (2012). Assessing the impact of formal and informal regulations on environmental and economic performance of Brazilian manufacturing firms. Environmental and Resource Economics, 52(1), 65-85.

García-Rodríguez, F. J., García-Rodríguez, J. L., Castilla-Gutiérrez, C., \& Major, S. A. (2013). Corporate social responsibility of oil companies in developing countries: From altruism to business strategy. Corporate Social Responsibility \& Environmental Management, 20(6), 371-384,

doi:https://doi.org/10.1002/csr.1320.

Godfrey, P. C. (2005). The relationship between corporate philanthropy and shareholder wealth: A risk management perspective. Academy of management review, 30(4), 777-798. 
Godfrey, P. C., Merrill, C. B., \& Hansen, J. M. (2009). The relationship between corporate social responsibility and shareholder value: An empirical test of the risk management hypothesis. Strategic management journal, 30(4), 425-445, doi:https://doi.org/10.1002/smj.750.

Goss, A., \& Roberts, G. S. (2011). The impact of corporate social responsibility on the cost of bank loans. Journal of Banking \& Finance, 35(7), $1794-1810$. Heckman, J. J. (1977). Sample selection bias as a specification error (with an application to the estimation of labor supply functions). National Bureau of Economic Research.

International Trade Centre (2020). SME Competitiveness Outlook 2020: COVID-19: The Great Lockdown and its Impact on Small Business. Geneva: ITC.

Jaggi, B., \& Freedman, M. (1992). An examination of the impact of pollution performance on economic and market performance: pulp and paper firms. Journal of business finance \& accounting 19(5), 697-713, doi:https://doi.org/10.1111/j.1468-5957.1992.tb00652.x.

Jo, H., \& Na, H. (2012). Does CSR reduce firm risk? Evidence from controversial industry sectors. Journal of Business Ethics, 110(4), 441-456.

Juergensen, J., Guimón, J., \& Narula, R. (2020). European SMEs amidst the COVID-19 crisis: assessing impact and policy responses. 1-12.

Kiernan, M. J. (2007). Universal Owners and ESG: leaving money on the table? Corporate Governance: An International Review, 15(3), 478-485.

Kontuš, E., \& Mihanović, D. (2019). Management of liquidity and liquid assets in small and medium-sized enterprises. Economic research-Ekonomska istraživanja, 32(1), 3247-3265.

Kottika, E., Özsomer, A., Rydén, P., Theodorakis, I. G., Kaminakis, K., Kottikas, K. G., et al. (2020). We survived this! What managers could learn from SMEs who successfully navigated the Greek economic crisis. $88,352-365$.

Kuckertz, A., Brändle, L., Gaudig, A., Hinderer, S., Reyes, C. A. M., Prochotta, A., et al. (2020). Startups in times of crisis-A rapid response to the COVID-19 pandemic. Journal of Business Venturing Insights, e00169.

Lee, D., \& Faff, R. (2009). Corporate sustainability performance and idiosyncratic risk: A global perspective. Financial Review, 44(2), $213-237$.

Lee, N., Sameen, H., \& Cowling, M. (2015). Access to finance for innovative SMEs since the financial crisis. Research policy, 44(2), $370-380$.

Lerner, J., Nanda, R., Howell, S. T., \& Townsend, R. (2020). Financial Distancing: How Venture Capital Follows the Economy Down and Curtails Innovation.

Lins, K. V., Servaes, H., \& Tamayo, A. (2017). Social capital, trust, and firm performance: The value of corporate social responsibility during the financial crisis. The Journal of Finance, 72(4), 1785-1824.

Lins, K. V., Servaes, H., \& Tamayo, A. (2019). Social capital, trust, and corporate performance: how CSR helped companies during the financial crisis (and why it can keep helping them). Journal of Applied Corporate Finance, 31(2), 59-71.

Magnanelli, B. S., \& Izzo, M. F. (2017). Corporate social performance and cost of debt: the relationship. Social Responsibility Journal, 13(2), 250-265, doi:https://doi.org/10.1108/SRJ-06-2016-0103.

Martin, D., Romero, I., \& Wegner, D. (2019). Individual, Organizational, and Institutional Determinants of Formal and Informal Inter-Firm Cooperation in SMEs. Journal of Small Business Management, 57(4), 1698-1711.

Muhammad, N., Scrimgeour, F., Reddy, K., \& Abidin, S. (2015a). The impact of corporate environmental performance on market risk: The Australian industry case. Journal of Business Ethics, 132(2), 347-362.

Muhammad, N., Scrimgeour, F., Reddy, K., \& Abidin, S. (2015b). The relationship between environmental performance and financial performance in periods of growth and contraction: Evidence from Australian publicly listed companies. Journal of Cleaner Production, 102, $324-332$.

Nandy, M., \& Lodh, S. (2012). Do banks value the eco-friendliness of firms in their corporate lending decision? Some empirical evidence. International Review of Financial Analysis, 25, 83-93, doi:https://doi.org/10.1016/j.irfa.2012.06.008.

OECD (2020). Corporate sector vulnerabilities during the Covid-19 outbreak: Assessment and policy responses.

Orr, J. (2020). The retail \& hospitality industry and COVID-19: Prepare for the future of work. https://www.retaildive.com/spons/the-retail-hospitality-industryand-covid-19-prepare-for-the-future-of-w/575809/. Accessed 20/08/2020.

Papadopoulos, T., Baltas, K. N., \& Balta, M. E. J. I. J. o. I. M. (2020). The use of digital technologies by small and medium enterprises during COVID-19: Implications for theory and practice. 102192.

Porter, M. E., \& Van der Linde, C. (1995). Toward a new conception of the environment-competitiveness relationship. Journal of economic perspectives, 9(4), 97-118.

PricewaterhouseCoopers (2013). 16th CEO Survey. http://www.pwc.com/gx/en/ceo-survey/2013/assets/pwc-16th-global-ceo-survey_jan-2013.pdf. Accessed $15 / 08 / 2020$. 
Rosenbaum, P. R., \& Rubin, D. B. (1983). The central role of the propensity score in observational studies for causal effects. Biometrika, 70(1), 41-55.

Seeger, M. W., \& Hipfel, S. J. (2007). Legal versus ethical arguments. The debate over corporate social responsibility, 155-166.

Sharfman, M. P., \& Fernando, C. S. (2008). Environmental risk management and the cost of capital. Strategic management journal, $29(6), 569-592$.

Sharma, S. (2001). Different strokes: regulatory styles and environmental strategy in the North-American oil and gas industry. Business Strategy and the Environment, 10(6), 344-364.

Wagner, M. (2005). How to reconcile environmental and economic performance to improve corporate sustainability: corporate environmental strategies in the European paper industry. Journal of Environmental Management, 76(2), 105-118.

Wagner, M., \& Schaltegger, S. (2004). The effect of corporate environmental strategy choice and environmental performance on competitiveness and economic performance:: an empirical study of EU manufacturing. European Management Journal, 22(5), 557-572.

Wellalage, N. H., \& Fernandez, V. (2019). Innovation and SME finance: Evidence from developing countries. International Review of Financial Analysis, doi:https://doi.org/10.1016/j.irfa.2019.06.009.

Wellalage, N. H., \& Locke, S. (2020). Formal credit and innovation: Is there a uniform relationship across types of innovation? International Review of Economics \& Finance.

Williams, T. A., \& Shepherd, D. A. (2018). To the rescue!? Brokering a rapid, scaled and customized compassionate response to suffering after disaster. Journal of Management Studies, 55(6), 910-942.

Williamson, D., Lynch-Wood, G., \& Ramsay, J. (2006). Drivers of environmental behaviour in manufacturing SMEs and the implications for CSR. Journal of Business Ethics, 67(3), 317-330, doi:10.1007/s10551-006-9187-1.

Zeidan, R., Boechat, C., \& Fleury, A. (2015). Developing a sustainability credit score system. Journal of Business Ethics, 127(2), $283-296$.

\section{Appendix}

\section{Table A.1: Variable description}




\begin{tabular}{|c|c|c|c|}
\hline Concept & Variable & Description & Type \\
\hline & \multirow[t]{2}{*}{ Liquidity_Dec } & \multirow{2}{*}{$\begin{array}{l}\text { This variable takes the value one if firm liquidity decreased mduering the } \\
\text { COVID-19 pandemic }\end{array}$} & 1 = yes; \\
\hline $\begin{array}{l}\text { Firm financial } \\
\text { status }\end{array}$ & & & $0=$ otherwise \\
\hline \multirow{2}{*}{$\begin{array}{l}\text { Firm financial } \\
\text { status }\end{array}$} & \multirow[t]{2}{*}{ Bank } & \multirow{2}{*}{$\begin{array}{l}\text { This variable takes the value one if the firm has used commercial banks as the } \\
\text { main mechanism for dealing with cash flow shortages dueing the the COVID-19 } \\
\text { pandemic }\end{array}$} & 1 = yes; \\
\hline & & & $0=$ otherwise \\
\hline \multirow{2}{*}{$\begin{array}{l}\text { Firm financial } \\
\text { status }\end{array}$} & \multirow[t]{2}{*}{ Bankruptucy } & \multirow{2}{*}{$\begin{array}{l}\text { This variable takes the value one if the firm filed for insolvancy or bankruptcy } \\
\text { during the COVID-19 pandemic }\end{array}$} & 1 = yes; \\
\hline & & & $0=$ otherwise \\
\hline \multirow[t]{2}{*}{$\begin{array}{l}\text { Environmental } \\
\text { performance }\end{array}$} & $\begin{array}{l}\text { Environmental } \\
\text { impact }\end{array}$ & \multirow[t]{2}{*}{ Log value of average index score of ten environment performance activities } & Continues \\
\hline & $\begin{array}{l}\text { reduction index } \\
\text { (EPIndex) }\end{array}$ & & \\
\hline \multirow{7}{*}{$\begin{array}{l}\text { Firm } \\
\text { Characteristics }\end{array}$} & \multirow{3}{*}{\multicolumn{2}{|c|}{ Medium-Between 20 and 99 employees }} & \\
\hline & & & 1 = yes; \\
\hline & & & $0=$ otherwise \\
\hline & & \multicolumn{2}{|l|}{ Micro \& Small- Between 0 and 19 employees } \\
\hline & & & 1 = yes; \\
\hline & & & $0=$ otherwise \\
\hline & Firm_Age & The number of years from the date of establishment. & Years \\
\hline \multirow{20}{*}{$\begin{array}{l}\text { Firm } \\
\text { ownership }\end{array}$} & \multirow[t]{2}{*}{ Sole_Prop } & \multirow[t]{2}{*}{ The current legal status of the firm is a sole proprietorship } & 1 = yes; \\
\hline & & & $0=$ otherwise \\
\hline & \multirow[t]{2}{*}{ Partnership } & \multirow[t]{2}{*}{ The current legal status of the firm is a partnership } & 1 = yes; \\
\hline & & & $0=$ otherwise \\
\hline & \multirow[t]{2}{*}{ Company } & \multirow[t]{2}{*}{ The current legal status of the firm is a company } & 1 = yes; \\
\hline & & & $0=$ otherwise \\
\hline & Foreign_Own\% & $\begin{array}{l}\text { Percentage of firms owned by private foreign individuals, companies or } \\
\text { organisations }\end{array}$ & Percentage \\
\hline & \multirow[t]{2}{*}{ Female_Own } & \multirow[t]{2}{*}{ At least one female owner among the owners of the firm. } & 1 = yes; \\
\hline & & & $0=$ otherwise \\
\hline & Family_Own & The same family owns a percentage of the firm & Percentage \\
\hline & Mgr_Exp & Manager's experience in the sector & Years \\
\hline & \multirow[t]{2}{*}{ Exporter } & \multirow[t]{2}{*}{ Firm sales were directly or indirectly exports } & 1 = yes; \\
\hline & & & $0=$ otherwise \\
\hline & \multirow[t]{2}{*}{ Innovation } & \multirow{2}{*}{$\begin{array}{l}\text { This variable takes value of one either product innovations and/or process } \\
\text { innovations occurring in a firm during the last three years. }\end{array}$} & 1 = yes; \\
\hline & & & $0=$ otherwise \\
\hline & \multirow[t]{2}{*}{ Bribes } & \multirow[t]{2}{*}{ Firm expected to give gifts to public officials "to get things done" } & 1 = yes; \\
\hline & & & $0=$ otherwise \\
\hline & \multirow[t]{2}{*}{ Credit_Constrints } & Firm has overdraft facility & 1 = yes; \\
\hline & & & $0=$ otherwise \\
\hline & Finance_Obstacle & Access to finance an obstacle to the current operations of the firm & 1 = yes; \\
\hline
\end{tabular}

Page 17/18 


\begin{tabular}{|llll}
\hline Credit_Info & $\begin{array}{l}\text { This index measures rules affecting the scope, accessibility, and quality of } \\
\text { credit information available through public or private credit registries. }\end{array}$ & $\begin{array}{l}0=\text { otherwise } \\
0=\text { low to } 8=\text { high } \\
\text { The higher values indicating the } \\
\text { availability of more credit } \\
\text { information }\end{array}$ \\
\hline Doing_Business & $\begin{array}{l}\text { Ease of doing index indicates the regulatory environment quality to starting and } \\
\text { operation of a local firm. }\end{array}$ & $\begin{array}{l}1 \text { to } 100 . \text { The low value } \\
\text { indicates most business- } \\
\text { friendly regulations. }\end{array}$ \\
\hline $\begin{array}{ll}\text { Bndustry } \\
\text { dummies }\end{array}$ & Percentage of firms using banks to finance working capital & Percentage \\
\hline
\end{tabular}

\section{Figures}
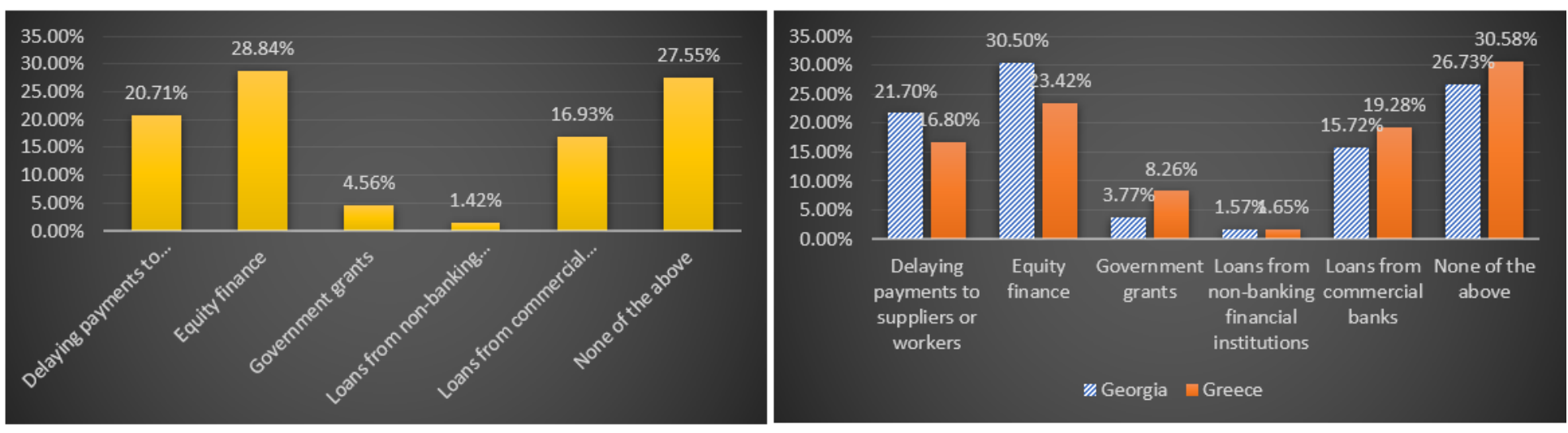

Full sample (A)

Micro, Small and Medium Enterprises (B)
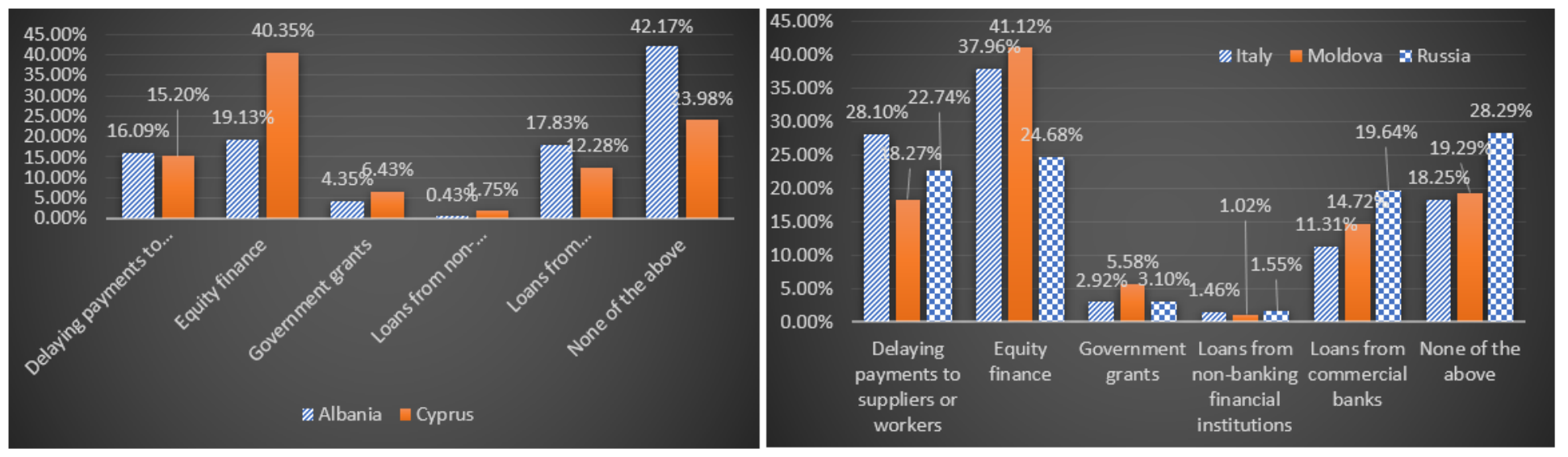

\section{Figure 1}

The main sources MSMEs have used to deal with cash flow shortages in the outbreak of COVID-19 